\title{
PENGARUH TERAPI TERTAWA TERHADAP TINGKAT DEPRESI PADA LANSIA DI PANTI UPTD GRIYA WREDA SURABAYA
}

\author{
Farida Umamah, Latifah Hidayah \\ Universitas Nahdlatul Ulama Surabaya, Jl. SMEA 57 Surabaya \\ umamahfarida@unusa.ac.id
}

\begin{abstract}
The laughter therapy on the depression level experienced by the elderly in UPTD Panti Griya Wreda Surabaya. One of the psychological problems experienced by the elderly are prone to depression, but it can be prevented by laughter therapy. But, in reality there are still elderly who look sad, moody, or silent. There are various causes for such things, for instance, having not visit, thinking of his child and family. The objective of this study was to find out the effect of the laughter therapy on the depression level experienced by the elderly in UPTD Panti Griya Wreda Surabaya. The design of the study used the Pre Experiment with the approach of one group pretest-posttest design. The population of the elderly aged 60-69 years is 30 people, and the sample was 28 people taken by simple random sampling method. The independent variable is laughter therapy, whereas the dependent variable is the level of depression. The instrument used was a questionnaire sheet and SOP. Statistical test using Wilcoxon test with a significance of $\alpha=0.05$. The results of the study showed that before the laughter therapy nearly a half, 35.7\% of the respondents experienced depression of medium level, and after the therapy nearly a half, 35.7 of the respondents was normal / did not experience depression. The result of Wilcoxon test on the laughter therapy showed the value of $\rho=0.000$ and the value of $\alpha=0.05$ meaning that $\rho<\alpha$ then $H 0$ is rejected, it means that the laughter therapy had an effect on the level of depression of the elderly in Panti UPTD Griya Wreda Surabaya. The conclusion of this study is that the more frequently the elderly followed the laughter therapy, the lower level of depression they experienced. Nurses are expected to resume activities of laugh therapy Griya Wreda Surabaya, that elderly people are motivated to do this on a regular basis and in groups.
\end{abstract}

Abstrak: Pengaruh terapi tertawa terhadap tingkat depresi pada lansia di panti UPTD Griya Wreda Surabaya. Salah satu masalah psikologis yang dialami para lansia adalah rentan terhadap terjadinya depresi, namun hal ini dapat dicegah dengan terapi tertawa. Tetapi pada kenyataannya masih terdapat lansia yang terlihat sedih, murung, menyendiri, ada berbagai macam penyebab misalnya tidak pernah dijenguk, memikirkan anak dan keluarganya. Tujuan dari penelitian ini adalah untuk mengetahui pengaruh terapi tertawa terhadap tingkat depresi pada lansia di UPTD Panti Griya Wreda Surabaya. Desain penelitian ini menggunakan Pra Experiment dengan pendekatan One Group Pretest-Posttest Design, populasi seluruh lansia yang mulai berusia 60-69 tahun sebesar 30 orang, sampel sebagian lansia sebesar 28 diambil dengan metode simple random sampling. Variabel independen terapi tertawa, variabel dependen adalah tingkat depresi. Instrumen yang digunakan adalah lembar kuisioner dan SOP. Uji statistik menggunakan uji Wilcoxon dengan nilai kemaknaan $\alpha=0,05$. Hasil penelitian menunjukkan sebelum diberikan terapi tertawa hampir setengahnya 35,7\% mengalami depresi sedang dan setelah diberikan terapi didapatkan hampir setengah dari responden $35,7 \%$ normal/tidak depresi. Hasil uji wilcoxon pada terapi tertawa didapatkan nilai $\rho=0,000$ dan nilai $\alpha=0,05$ berarti $\rho<\alpha$ maka $\mathrm{H}_{0}$ ditolak, artinya ada pengaruh terapi tertawa terhadap tingkat depresi pada lansia di UPTD Panti Griya Wreda Surabaya.Simpulan dari penelitian ini semakin rutin mengikuti terapi tertawa semakin rendah tingkat depresi lansia. Diharapkan perawat bisa melanjutkan kegiatan terapi tertawa di Panti Griya Wreda Surabaya, sehingga lansia termotivasi untuk melakukan hal ini secara rutin dan berkelompok.

Kata kunci: Terapi tertawa, Tingkat depresi, Lansia 


\section{PENDAHULUAN}

Proses menua merupakan proses alamiah, yang berarti seseorang telah melalui tiga tahap kehidupan yaitu anak, dewasa dan tua. Tiga tahap ini berbeda, baik secara biologis, maupun psikologis. Salah satu masalah proses psikologis yang terjadi pada tahap tua adalah depresi. Depresi adalah perasaan sedih, ketidakberdayaan, dan pesimis, yang berhubungan dengan suatu penderitaan. Depresi dapat berupa serangan yang ditujukan kepada diri sendiri atau perasaan marah yang dalam (Nugroho, 2008). Depresi merupakan suatu gangguan mood, yang ditandai dengan kemurungan, kelesuhan, tidak bergairah, perasaan tidak berguna, putus asa dan sebagainya (Nasir, 2011). Fenomena ini jelas mendatangkan sejumlah konsekuensi, antara lain timbulnya masalah fisik, mental, sosial, serta kebutuhan pelayanan kesehatan (Nugroho, 2008).

Pada tahun 2005-2010, jumlah lanjut usia akan sama dengan jumlah anak balita, yaitu sekitar 19,3 juta jiwa $( \pm 9 \%)$ dari jumlah penduduk. Bahkan pada tahun 20202025, Indonesia akan menduduki peringkat Negara dengan struktur dan jumlah penduduk lanjut usia setelah RRC, India, dan Amerika Serikat, dengan umur harapan hidup diatas 70 tahun (Nugroho, 2008). Kementrian kesehatan menyatakan bahwa dari populasi orang dewasa di Indonesia yang mencapai 150 juta jiwa, sekitar 11,6\% atau 17,4 juta jiwa mengalami gangguan mental emosional atau gangguan kesehatan jiwa berupa gangguan kecemasan dan depresi (Hidayat, 2011). Data WHO menunjukkan bahwa pria pada usia lebih dari 65 tahun hampir 5-10\% dari populasi masyarakat yang menderita depresi, sedangkan wanita, angka depresi lebih tinggi sekitar 15-17\% (Nasir, 2011). Berdasarkan data menurut Bangsoe (2009) prevalensi depresi pada lansia di dunia berkisar $8-15 \%$ dan hasil meta analisis dari laporan Negara- negara di dunia mendapatkan prevalensi rata-rata depresi pada lansia adalah $13,5 \%$. Berdasarkan data awal yang dilakukan peneliti pada bulan Maret 2016 di Panti Griya Wreda Surabaya dengan cara observasi dan komunikasi kepada 8 lansia, di dapat 5 orang $(62,5 \%)$ terlihat ekspresi wajah sedih, tampak menyendiri, dan murung karena tidak pernah di jenguk dan memikirkan istri, anak dan keluarganya. Sedangkan 3 orang $(37,5 \%)$ lansia sangat kooperatif dan aktif dalam kegiatan dipanti karena sering di jenguk oleh keluarganya.

Adanya konflik keluarga serta kondisi lingkungan yang buruk dan berkurangnya interaksi sosial dengan orang yang dicintai juga bisa menjadi pemicu depresi pada lansia. Depresi dapat menimbulkan dampak negatif misalnya: perasaan tidak berguna, mudah marah, sedih, merasa disingkirkan dan tidak dibutuhkan lagi. Selain itu, stres juga dapat menyebabkan seseorang menjadi lebih sensitif atau peka terhadap depresi (Haryadi, 2012). Respon tahap awal tubuh HPA (Hipotalamic-Pituitary-Adrenal) memegang peranan penting dalam beradaptasi terhadap stres eksternal maupun internal dan pada keadaan depresi terjadi peningkatan aktivitas HPA yang ditandai dengan pelepasan CRH (Corticotropinreleasing-hormone) dari hipotalamus. $\mathrm{CRH}$ banyak ditemukan di PVN (ParaventricularNucleus) hipotalamus. Kemudian pelepasan CRH dari hipotalamus dirangsang oleh noradrogenik, serotonergik dan kolinergik yang menyebabkan terjadinya depresi. Peningkatan rangsangan terhadap hipofisis anterior menyebabkan sekresi ACTH (Adreno Cortico Tropin Hormone). ACTH berperan merangsang keluarnya kortisol dari korteks adrenal. Kemudian peningkatan ACTH pada keadaan depresi bila berlangsung lama dapat menimbulkan hiperaktivitas kelenjar adrenal dan kortisol setelah itu, yang dikeluarkan dari kelenjar adrenal lalu masuk dalam sirkulasi umum, 
dimana pada pasien depresi terjadi peningkataan kadar kortisol terutama pada sore dan malam hari. Sehingga penting untuk mempertahankan kondisi mental, fisik seseorang. (Nurmiati, 2005). Banyaknya penyebab depresi yaitu: masalah fisik, genetik, jenis kelamin, penyalahgunaan obat dan obat-obatan (Kaplan, 2010).

Adapun upaya penanganan dan terapi guna memperbaiki kondisi lansia tersebut sangat diperlukan. Pada umumnya, terapi depresi pada lansia berupa terapi farmakologis, obat dapat membantu secara sitomatis, akan tetapi menyebabkan efek yang merugikan bagi lansia jika digunakan dalam kurun waktu yang lama (Stuart, 2006). Oleh karena itu perlu dikembangkan terapi non farmakologis yang dapat menurunkan depresi pada lansia untuk tetap awet muda dan yang muda tetap muda, serta mempererat hubungan antara anggota keluarga. (Prof. Dr. Lucille Name how, pakar yang menangani masalah penuaan Connecticut, America Serikat). Salah satunya terapi non farmakologis yang dapat mencegah dan mengatasi depresi pada lansia adalah psikodinamik, psikoterapi interpersonal, terapi kognitif beck, terapi perilaku, terapi humanistik eksistensial dan terapi tertawa (laughter therapy) Kaplan (2010) dan Setyoadi (2011).

Terapi tertawa merupakan tertawa yang dimulai dengan tahap demi tahap. Sehingga efek yang dirasakan bagi yang tertawa benar-benar bermanfaat. Terapi tertawa untuk mengurangi stress sudah banyak dilakukan orang. Tertawa 5-10 menit bisa merangsang pengeluaran endhorphin dan serotonin, yaitu sejenis morfin alami tubuh dan juga melatonin. Ketiga zat ini merupakan zat baik untuk otak sehingga kita bisa merasa lebih tenang. Terapi tertawa merupakan teknik yang mudah dilakuakan, tetapi efeknya sangat luar biasa, bahkan dapat menyembuhkan pasien dengan gangguan mental akibat stres berat (Padila,
2013). Tertawa dapat dihasilkan dari humor atau dari terapi tertawa yang dilakukan dalam kelompok dan tertawa ini bisa berlangsung 15 detik (Setyoadi, 2011). Beberapa penelitian mengatakan tentang manfaat terapi tertawa seperti yang dilakukan di India, tertawa dapat menangani kecemasan dan perasaan depresi, yaitu sebanyak 19,5\% (Kataria, 2004). Penelitian yang dilakukan oleh Anggun (2011) mengatakan bahwa terapi tertawa dapat menurunkan stress pekerja. Penelitian lain Katona (2012) tertawa menyebabkan menurunnya tekanan darah dalam diri individu, meningkatkan energi dalam merespon stress, memberi perasaan rileks, mempertahankan kesehatan mental dan emosi lebih positif. Penelitian yang diterbitkan dalam jurnal Geriatrics and gerontology international para peneliti menemukan terapi tawa bisa mengatasi depresi pada individu. (Kataria, 2004). Tertawa terbukti memperbaiki suasana hati dalam konteks sosial, membantu membentuk pola pikir yang lebih positif. (Dumbre, 2012).

\section{METODE}

Desain penelitian yang digunakan pre eksperimental yaitu one-group pra-post test design dengan cara kelompok subjek di observasi sebelum dilakukan intervensi, kemudian diobservasi lagi setelah dilakukan intervensi.

\begin{tabular}{llll}
\hline Subjek & Pra-test & Perlakuan & Pasca-test \\
\hline K & O & I & O1 \\
& Waktu 1 & Waktu 2 & Waktu 3 \\
\hline
\end{tabular}

Keterangan:

$\mathrm{K}$ : subjek (lansia yang mulai umur 60-69 tahun)

O1: observasi depresi sebelum terapi tertawa I : intervensi (terapi tertawa)

O2: observasi depresi sesudah terapi tertawa

Populasi penelitian ini adalah seluruh lansia yang mulai berusia 60-69 tahun di 
Panti UPTD Griya Wreda Surabaya sebesar 30 orang, besar sampel 28 responden. Pengambilan sampel yang dilakukan dalam peneliti ini menggunakan Probability sampling dengan teknik simple random sampling.

Variabel independen dalam penelitian ini adalah terapi tertawa dan variabel dependen adalah tingkat depresi.

Variabel dependen instrumen pengumpulan data yang digunakan peneliti adalah lembar kuisioner. Alat ukur yang digunakan adalah kuisioner penilaian tingkat depresi DASS 42 (Depression, Anxiety, Stress Scale) untuk mengetahui tingkat depresi.

Pengolahan data pada penelitian ini dilakukan dengan beberapa tahapan sebagai berikut: Dilakukan editing, scoring, coding, procceesing, cleaning dan tabulating. Kemudian di analisis menggunakan uji Wilcoxon Rank Test.

Tahap pelaksanaan terapi tertawa

1. Lakukan pemanasan terlebih dahulu dengan cara menghirup napas melalui hidung, tahan nafas selama 15 detik dengan pernapasan perut. Lalu hembuskan secara perlahan melalui mulut. Lakukan tiga kali berturut-turut.

2. Kemudian pemandu terapi mengemukakan pada kelompok bahwa terapi akan dimulai.

3. Pemandu kemudian tertawa lebar (haahaa-haa-hii-hii-huu-huu) dan diikuti oleh anggota kelompok dengan saling berhadapan, bertatap muka dan menertawakan satu sama lain.

4. Tertawa ini bisa berlangsung selama 15 detik. Setelah 5 menit, kembali tertawa (menyuarakan hii-hii-hii). Bila kurang kompak, lakukan kembali dengan menyuarakan (huu-huu-huu). Sampai semua kompak saat melakukan latihan terapi tertawa.
5. Setelah dilakukan pemanasan, kemudian pemandu memberikan media untuk terapi tertawa dengan menggunakan video lucu.

6. Kemudian lakukan 4 kali seminggu selama 15 detik pada jam 09.00 pagi.

\section{HASIL DAN PEMBAHASAN}

1. Data umum

a. Distribusi responden berdasarkan usia

Karakteristik umur yang ditemukan dalam hasil penelitian menurut Burnside (1979) dikutip Nugroho (2008), klasifikasi lansia meliputi Young Old (usia 60-69 tahun), Middle age old (usia 70-79 tahun), Old-old (usia 80-89 tahun), Very old-old (usia 90 tahun keatas).

Tabel 1 Distribusi frekuensi responden berdasarkan umur pada terapi tertawa terhadap tingkat depresi di UPTD Panti Griya Wreda Surabaya.

\begin{tabular}{cccc}
\hline No & Umur (tahun) & $\begin{array}{c}\text { Frekuensi } \\
(\mathrm{n})\end{array}$ & $\begin{array}{c}\text { Persentase } \\
(\%)\end{array}$ \\
\hline 1. & $60-69$ & 28 & 100.0 \\
\hline & Jumlah & 28 & 100.0
\end{tabular}

Sumber: Data Primer, Mei 2016

Berdasarkan tabel 1 menunjukkan bahwa seluruh dari responden (100\%) memiliki umur 60-69 tahun.

b. Distribusi responden berdasarkan jenis kelamin

Dalam hasil penelitian responden ini diuraikan karakteristik berdasarkan jenis kelamin.

Tabel 2 Distribusi frekuensi responden jenis kelamin pada terapi tertawa terhadap tingkat depresi di UPTD Panti Griya Wreda Surabaya.

\begin{tabular}{cccc}
\hline No & $\begin{array}{c}\text { Jenis } \\
\text { Kelamin }\end{array}$ & Frekuensi (n) & $\begin{array}{c}\text { Persentase } \\
(\%)\end{array}$ \\
\hline 1. & Laki & 10 & 35.7 \\
2. & Perempuan & 18 & 64.3 \\
\hline & Jumlah & 28 & 100.0
\end{tabular}

Sumber: Data Primer, Mei 2016 
Berdasarkan tabel 2 menunjukkan bahwa dari 28 responden, didapatkan sebagian besar $(64,3 \%)$ memiliki jenis kelamin perempuan.

\section{Data Khusus}

a. Distribusi tingkat depresi pada lansia sebelum diberikan terapi tertawa

Hasil penelitian mengenai karakteristik tingkat depresi pada lansia sebelum dilakukan terapi dapat dilihat pada tabel 3 dengan kategori tingkat normal/tidak depresi, tingkat depresi ringan, tingkat depresi sedang, dan tingkat depresi berat.

Tabel 3 Distribusi frekuensi responden berdasarkan tingkat depresi pada lansia sebelum diberikan terapi tertawa di UPTD Panti Griya Wreda Surabaya.

\begin{tabular}{clcc}
\hline No & $\begin{array}{c}\text { Tingkat Depresi } \\
(\text { Pre })\end{array}$ & $\begin{array}{c}\text { Frekuensi } \\
(\mathrm{n})\end{array}$ & $\begin{array}{c}\text { Persentase } \\
(\%)\end{array}$ \\
\hline 1. & Normal/tidak & 4 & 14.3 \\
& depresi & & \\
2. & Depresi ringan & 8 & 28.6 \\
3. & Depresi sedang & 10 & 35.7 \\
4. & Depresi berat & 6 & 21.4 \\
\hline & $\quad$ Jumlah & 28 & 100.0
\end{tabular}

Sumber: Data Primer, Mei 2016

Berdasarkan tabel 3 menunujukkan bahwa dari 28 responden, didapatkan hampir setengahnya $(35,7 \%)$ mengalami depresi sedang.

b. Distribusi tingkat depresi pada lansia sesudah diberikan terapi tertawa

Hasil penelitian mengenai karakteristik tingkat depresi pada lansia sesudah dilakukan terapi dapat dilihat pada tabel 4 dengan kategori tingkat normal/tidak depresi, tingkat depresi ringan, tingkat depresi sedang, dan tingkat depresi berat.

Tabel 4 Distribusi frekuensi responden berdasarkan tingkat depresi pada lansia sesudah diberikan terapi tertawa di UPTD Panti Griya Wreda Surabaya.

\begin{tabular}{llcc}
\hline No & $\begin{array}{c}\text { Tingkat Depresi } \\
(\text { Post })\end{array}$ & $\begin{array}{c}\text { Frekuensi } \\
(\mathrm{n})\end{array}$ & $\begin{array}{c}\text { Persentase } \\
(\%)\end{array}$ \\
\hline 1. & Normal/tidak & 10 & 35.7 \\
& depresi & & \\
2. & Depresi ringan & 9 & 32.1 \\
3. & Depresi sedang & 9 & 32.1 \\
4. & Depresi berat & 0 & 0 \\
\hline & \multicolumn{1}{c}{ Jumlah } & 28 & 100.0
\end{tabular}

Sumber: Data Primer Mei 2016

Berdasarkan tabel 4 menunujukkan bahwa dari 28 responden, didapatkan hampir setengahnya $(35,7 \%)$ normal/tidak depresi.

c. Pengaruh tingkat depresi lansia pre-post terapi tertawa

Hasil penelitian mengenai pengaruh tingkat depresi antara pre test dan post test terapi tertawa dapat dilihat pada gambar 1 berikut:

Gambar 1 Diagram batang tentang pengaruh tingkat depresi pada lansia sebelum dan sesudah diberikan terapi tertawa di UPTD Panti Griya Wreda Surabaya.

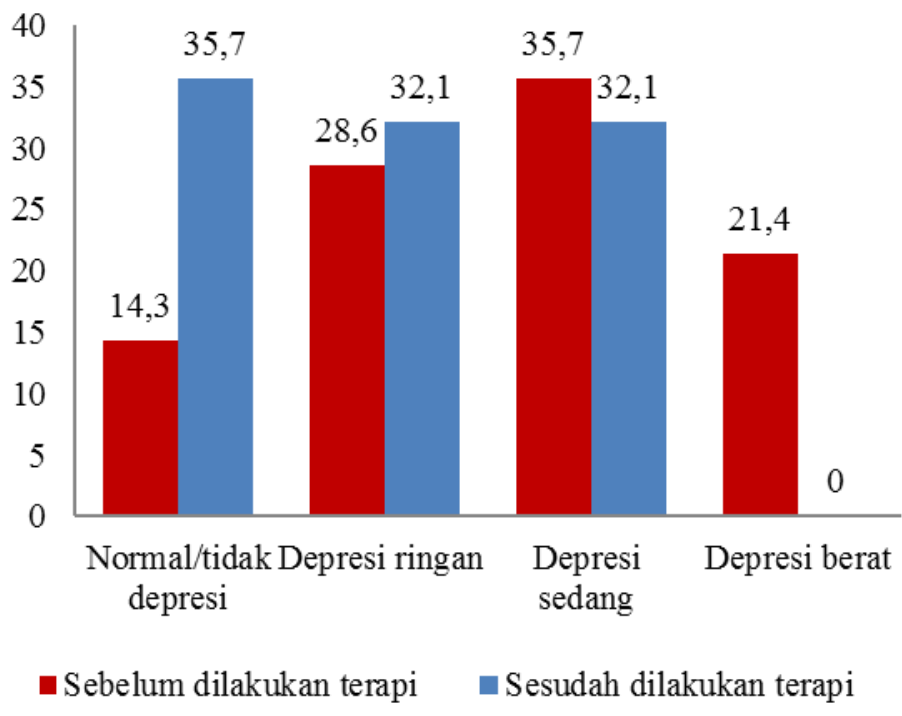

Berdasarkan gambar 1 didapatkan hasil penelitian bahwa dari 28 responden hampir setengahnya mengalami penurunan tingkat depresi pada lansia. 


\section{PEMBAHASAN}

\section{Identifikasi Tingkat Depresi Pada Lansia Sebelum (Pre) Diberikan Terapi tertawa}

Hasil penelitian pada tabel 3 menunjukkan bahwa dari 28 responden, didapatkan hampir setengahnya $(35,7 \%)$ responden mengalami depresi sedang, sebelum diberikan terapi tertawa. Dengan sebagian ekspresi wajah terlihat tidak senyum, diam, seperti tidak mau tau dan banyak yang dipikirkan. Berdasarkan fakta yang terjadi depresi yang dialami oleh lansia yaitu merasa sedih yang berlebihan $(76,7 \%)$, pesimis $(100 \%)$, berfikiran hal yang negatif, merasa hilang harapan dan putus asa (92,5\%), merasa hidup tidak berarti $(67,8 \%)$, merasa tidak berharga $(58,9 \%)$ dan terkadang sulit untuk meningkatkan inisiatif dalam melakukan sesuatu $(85,7 \%)$.

Hal ini juga didukung oleh Wash, 1997 dalam Lilik, 2011 mengatakan bahwa depresi pada orang lanjut usia dimanifestasikan dengan adanya keluhan merasa tidak berharga, sedih yang berlebihan, murung, tidak bersemangat, merasa kosong, tidak ada harapan, menyalahkan diri sendiri, ide-ide pikiran bunuh diri dan pemeliharaan diri yang kurang bahkan penelantaran diri.

Depresi dapat dipengaruhi oleh beberapa faktor, diantaranya dipengaruhi oleh umur. Berdasarkan pada tabel 1 menunjukkan bahwa seluruh dari responden (100\%) memiliki umur 60-69 tahun. Faktor umur merupakan salah satu determinasi yang mempengaruhi tingkat depresi, yang artinya semakin tua umur lansia maka depresi yang dialami semakin berat.

Hal ini juga didukung oleh Ibrahim (2006) peningkatan secara bertahap dengan gangguan status mental diatas umur 60 tahun. Menurut Lumbantobing (2011) menjelaskan bahwa didapatkan kemunduran pada beberapa kemampuan dan terdapat lebih banyak kemunduran pada beberapa jenis kemampuan pada umur diatas 60 tahun dan meningkat pada lansia diatas 80 tahun.

Berdasarkan tabel 2 menunujukkan bahwa dari 28 responden didapatkan sebagian besar $(64,3 \%)$ lansia berjenis kelamin perempuan. Depresi umumnya mudah terjadi pada perempuan. Hal ini disebabkan pola pikir perempuan lebih cenderung menggunakan emosional dari pada rasional. Sehingga pola komunikasi perempuan berbeda dengan laki-laki, perempuan lebih cenderung memikirkan masalahnya dan kurang mengkomunikasikan dengan orang lain sehingga emosinya labil yang sering menyebabkan depresi. Apabila dibiarkan berlangsung dalam waktu yang lama akan mengakibatkan stres peran yang dapat memicu terjadinya depresi. Mencegah depresi pada lansia, dapat dilakukan dengan memberikan kegiatan yang positif kepada para lansia, seperti mengajak untuk berkumpul tertawa bersama sehingga terdapat komunikasi yang baik antara perawat dengan lansia.

Hal ini juga didukung oleh Jeffrey (2003) wanita memilih kecenderungan hampir dua kali lipat lebih besar dari pada pria untuk mengalami depresi. Menurut Kaplan (2010) perempuan lebih mungkin untuk merenungkan hal-hal yang tidak akan menguntungkan mereka, yang akhirnya mengakibatkan perasaan tidak berdaya dan putus asa.

\section{Identifikasi Tingkat Depresi Pada Lansia Sesudah (Post) Diberikan Terapi Tertawa}

Berdasarkan tabel 4 menunujukkan bahwa dari 28 responden, didapatkan hampir setengahnya $(35,7 \%)$ normal/tidak depresi dengan ekspresi wajah terlihat bahagia, senyum, tertawa, seperti tidak ada beban dipikiran. Hampir setengah dari responden $(32,1 \%)$ mengalami depresi ringan dengan 
ekspresi wajah terlihat senyum tetapi tidak begitu lepas. Kemudian, hampir setengahnya $(32,1 \%)$ mengalami depresi sedang dengan sebagian ekspresi wajah terlihat tidak senyum, diam, seperti tidak mau tau dan banyak yang dipikirkan.

Lansia yang telah diberikan terapi tertawa dengan durasi 10-15 menit dilakukan dengan teknik latihan pemanasan, menampilkan video dengan durasi kurang lebih 5 menit dan lansia bisa tertawa lepas kurang lebih 15 detik. Kemudian terapi tertawa ini dilaksanakan 4 kali dalam 15 detik selama 1 minggu mengalami normal/tidak depresi karena terapi tertawa yang efektif, mudah, murah dan dapat merubah perasaan atau mood yang menjadikan rasa senang, ceria dan bahagia serta dapat mengurangi depresi. Tertawa dapat merangsang pengeluaran endorphin dan serotonin yaitu sejenis morfin alami tubuh dan juga melatonin. Ketiga zat ini merupakan zat baik untuk otak sehingga kita bisa merasa lebih tenang.

Tertawa secara eksperimental dengan teknik yang mudah dilakukan, tetapi efeknya sangat luar biasa, bahkan dapat menyembuhkan pasien dengan gangguan mental akibat stress berat (Padila, 2013).

\section{Menganalisis Pengaruh Terapi Tertawa Terhadap Tingkat Depresi Pada Lansia Di UPTD Panti Griya Wreda Surabaya}

Berdasarkan gambar 1 bahwa ada pengaruh terapi tertawa pada lansia di UPTD Panti Griya Wreda Surabaya. Didapatkan hasil penelitian bahwa dari 28 responden hampir setengahnya mengalami penurunan tingkat depresi pada lansia. Sebelum diberikan terapi tertawa, responden yang normal/tidak mengalami depresi dari $14,3 \%$ meningkat menjadi $35,7 \%$, yang mengalami tingkat depresi ringan dari $28,6 \%$ meningkat menjadi $32,1 \%$, yang mengalami tingkat depresi sedang dari $35,7 \%$ sedikit menurun menjadi $32,1 \%$, sedangkan yang mengalami tingkat depresi berat dari 21,4\% turun menjadi 0\%. Bahwa setelah dilakukan terapi tertawa selama 4 kali dalam 1 minggu lansia bisa mengontrol emosi, pikiran serta perasaan didalam hati dan termotivasi untuk meningkatkan inisiatif dalam mengikuti kegiatan dipanti. Setelah itu hasil presentase normal/tidak depresi yang lebih banyak, kemudian hasil presentase depresi ringan dan sedang sama. Sedangkan hasil presentase depresi berat menjadi tidak ada.

Berdasarkan hasil uji Wilcoxon Sign Rank Test didapatkan nilai $\rho=0,000$ dan nilai $\alpha=0,05$ berarti $\rho<\alpha$ maka $\mathrm{H}_{0}$ ditolak, artinya ada pengaruh terapi tertawa terhadap tingkat depresi pada lansia di UPTD Panti Griya Wreda Surabaya.

Dari data tersebut menunujukkan bahwa adanya pengaruh terapi tertawa terhadap tingkat depresi, didukung berdasarkan penurunan normal/tidak depresi yang disebabkan oleh terapi tertawa.

Terapi tertawa adalah ekspresi jiwa atau emosional yang diperlihatkan melalui raut wajah dan bunyi-bunyian tertentu. Tertawa merupakan suatu reaksi dari suatu stimulus tertentu yang terlihat dari ekspresi bahagia atau perasaan senang. Ketika tertawa tubuh akan melepaskan hormon endorphin yang memberikan rasa nyaman bagi tubuh (sebagai penenang alami), hormon stres akan berkurang dan meningkatkan perasaan bahagia. Endhorphine adalah hormon yang dilepaskan oleh kelenjar HPA (Hipotalamic Pituitary Adrenal) salah satu kelenjar penghasil hormon yang berada dibawah hipotalamus dan hormon ini akan disekresikan apabila seseorang merasa nyaman serta rileks. Kemudian peningkatan hormone endorphin yang dihasilkan dalam terapi tertawa akan memberikan dampak positif bagi psikologis dan fisik seseorang seperti: menekan emosi atau stress mental, meningkatkan hubungan interpersonal, meningkatkan rasa percaya diri, 
meningkatkan hubungan sosial, merangsang jantung dan sirkulsi darah, meningkatkan kekebalan tubuh (Katona, 2012) sehingga tertawa akan mempengaruhi hipofisis di otak untuk melepaskan hormone endorphin. Endhorpin dapat memberikan rasa rileks dan tenang sehingga dapat mengurangi depresi. Depresi dapat menimbulkan dampak negatif misalnya: perasaan tidak berguna, mudah marah, sedih, merasa disingkirkan dan tidak dibutuhkan lagi. Selain itu, stres juga dapat menyebabkan seseorang menjadi lebih sensitif atau peka terhadap depresi (Haryadi, 2012). Respon tahap awal tubuh HPA (Hipotalamic-Pituitary-Adrenal) memegang peranan penting dalam beradaptasi terhadap stres eksternal maupun internal dan pada keadaan depresi terjadi peningkatan aktivitas HPA yang ditandai dengan pelepasan CRH (Corticotropin-releasing-hormone) dari hipotalamus. $\mathrm{CRH}$ banyak ditemukan di PVN

(Paraventricular-Nucleus) hipotalamus. Kemudian pelepasan CRH dari hipotalamus dirangsang oleh noradrogenik, serotonergik dan kolinergik yang menyebabkan terjadinya depresi. Peningkatan rangsangan terhadap hipofisis anterior menyebabkan sekresi ACTH (Adreno Cortico Tropin Hormone). ACTH berperan merangsang keluarnya kortisol dari korteks adrenal. Kemudian peningkatan ACTH pada keadaan depresi bila berlangsung lama dapat menimbulkan hiperaktivitas kelenjar adrenal dan kortisol setelah itu, yang dikeluarkan dari kelenjar adrenal lalu masuk dalam sirkulasi umum, dimana pada pasien depresi terjadi peningkataan kadar kortisol terutama pada sore dan malam hari. Sehingga penting untuk mempertahankan kondisi mental, fisik seseorang (Nurmiati, 2005).

Bahwa faktor-faktor diatas menimbulkan terjadinya depresi sehingga dengan dilakukan kegiatan terapi tertawa dapat menurunkan depresi pada lansia.

\section{B. Keterbatasan}

Keterbatasan yang dialami oleh peneliti dalam penyusunan skripsi ini antara lain:

1. Jumlah sampel yang hanya dibatasi umur

2. Keterbatasan sarana prasarana pada saat melakukan intervensi maka lansia dibagi menjadi 2 kelompok dengan 14 lansia kelompok pertama dan 14 lansia kelompok kedua.

3. Tidak semua responden bisa mengalami tertawa lepas.

4. Keterbatasan waktu peneliti dalam penelitian ini hanya mampu melakukan terapi 4 kali dalam seminggu, dikarenakan setelahnya harus mengolah data hasil penelitian.

5. Keterbatasan tingkat kuisioner sulit dimengerti lansia karena tidak sesuai dengan kemampuan.

6. Kemampuan peneliti masih kurang karena peneliti masih termasuk taraf pemula sehingga peneliti butuh saran yang mendukung dalam melakukan penelitian.

\section{SIMPULAN DAN SARAN \\ Simpulan}

1) Lansia sebelum diberikan terapi tertawa di UPTD Panti Griya Wreda Surabaya hampir setengahnya mengalami depresi sedang.

2) Lansia setelah diberikan terapi tertawa di UPTD Panti Griya Wreda Surabaya hampir setengahnya normal/tidak depresi.

3) Ada pengaruh terapi tertawa terhadap tingkat depresi pada lansia di UPTD Panti Griya Wreda Surabaya

\section{Saran}

1. Teoritis

Hasil penelitian ini diharapkan dapat digunakan sebagai data penelitian berikutnya dan dapat bermanfaat bagi perawat dalam mengembangkan metode 
penurunan depresi pada lansia sehingga dapat menambah wawasan ilmu pengetahuan bagi perawat maupun mahasiswa keperawatan.

2. Praktis

a. Bagi Peneliti

Sebagai tambahan ilmu pengetahuan dan pengalaman dalam dunia kesehatan dan dapat menerapkan terapi tertawa untuk menurunkan tingkat depresi serta sebagai acuan untuk melakukan penelitian selanjutnya.

b. Bagi Profesi Keperawatan

Diharapkan hasil penelitian ini dapat digunakan sebagai bahan pertimbangan dalam rangka meningkatkan mutu dan kualitas asuhan keperawatan yang dilakukan secara independen untuk memberikan intervensi keperawatan khusunya keperawatan gerontik.

c. Bagi Institusi Pendidikan Universitas Nahdlatul Ulama Surabaya

Sebagai bahan referensi atau literatur bagi penelitian selanjutnya yang berkaitan dengan pengaruh terapi tertawa terhadap tingkat depresi pada lansia dan sebagai bahan bacaan atau tambahan pengetahuan di perpustakaan.

d. Bagi UPTD Panti Griya Wreda Surabaya Diharapkan petugas panti dapat memantau konsisi psikologis lansia untuk mengurangi tingkat depresi pada lansia dan menambahkan pengetahuan dengan memfasilitasi terapi-terapi yang menunjang agar lansia merasa bahagia, rileks seperti terapi tertawa.

e. Bagi Lansia di UPTD Panti Griya Wreda Surabaya

Bagi lansia dapat termotivasi untuk melakukan terapi yang akan mengurangi beban psikologis seperti terapi tertawa dan kegiatan yang disukai oleh para lansia yang tidak menyebabkan beban psikologis terganggu.

\section{DAFTAR PUSTAKA}

Anggun, Nurtjahjanti. 2011. Pengaruh Penerapan Tingkat Stress Kerja Pada Pegawai Kereta Api. Jurnal psikologi

Bongsoe,S. 2009. Lansia Rentan Alami Depresi.http://www.litbang.depkes. go.id/aktual/kliping/depresi230707.h tm. Diakses tanggal 11 Februari 2016

Azizah, Lilik Ma'rifatul. 2011. Keperawatan Lanjut Usia. Edisi I, Yogjakarta, Graha Ilmu

Dumbre, Satish. 2012. Laughter Therapy. Journal of Pharmaceutical and Scientitic Inovation Org. 23-24

Ibrahim, Ayub Sani. 2011. Gangguan Alam Perasaan, Manik Depresi. Edisi I. Tanggerang, Jelajah Nusa

Kataria. 2004. Laugh For No Reason (Terapi Tertawa). Jakarta, PT. Gramedia, Pustaka Utama

Kaplan, Sadock dkk. 2010. Sinopsis Psikiatri: Ilmu Pengetahuan Perilaku Psikiatri Klinis. Jilid I. Editor: Dr. I. Made Wiguna S. Jakarta, Bina Rupa Aksara

Katona, C., Cooper, C., Robertson, M. 2012. At a Glance Psikiatri Edisi Keempat. Jakarta, Erlangga

Lumbantobing. 2011. Neurogeriatri. Edisi Dua. Jakarta: Balai Penerbit FKUI

Nugroho, Wahjudi. 2008. Keperawatan Gerontik \& Geriatrik. Edisi 3. Jakarta, EGC 
Nasir, Abdul \& Muhith, Abdul. 2011. Dasar-dasar Keperawatan Jiwa: Pengantar dan Teori. Jakarta, Salemba Medika

Nurmiati, Amir. 2005. Depresi: Aspek Neurobiology, Diagnosis dan Tatalaksana. Jakarta, Balai Penerbit FKUI

Padila. 2013. Buku Ajar Keperawatan Gerontik. Yogjakarta, Nuha Medika

Setyoadi, Kushariyadi. 2011. Terapi Modalitas Keperawatan Pada Klien Psikogeriatrik. Jakarta, Salemba Medika 